\title{
Konglomerasi Media Antara Konvergensi Media dan Kebebasan Berpendapat
}

\author{
Muhammad Hilmy Aziz \\ Mahasiswa Program Magister Ilmu Komunikasi FISIP, Pascasarjana Universitas Diponegoro, \\ Semarang \\ Email: hilmyaziz23@yahoo.co.id
}

\begin{abstract}
Amid the rampant practice of the media conglomerate, tucked into some of the issues that seem trivial. But very influential on condition that society can not escape the tendency to consume media. Especially in terms of freedom of the press and speech which seemed still fettered though has long been in the era of reform and openness of information. The results found in this study has not been able to realize that media public space freely because the percentage interests of the media owners are still likely to be high compared to the citizens; Media only be used as a commodity that businesses can reap the benefits by a large amount; Media owners as well as the media have hired top industrial conglomerate itself also in the world of politics. Media owners simply commanding voice to be broadcast and the corresponding interests. All forms of existing content directed to be able to mobilize public opinion to have the same perception as the will of the owner of the media. So that the content that is highly disproportionate in the present data, facts that really happened.
\end{abstract}

Keywords: Media conglomerate, Convergence Media, Freedom of the Press, Freedom of Opinion

\begin{abstract}
Abstrak
Ditengah maraknya praktik konglomerasi media, terselip beberapa permasalahan yang nampaknya sepele. Akan tetapi sangat berpengaruh pada kondisi masyarakat yang kecenderungan tidak bisa lepas dalam mengonsumsi media. Terlebih dalam hal kebebasan pers dan berpendapat yang seakan masih terbelenggu walaupun telah lama berada pada era reformasi dan keterbukaan informasi. Hasil yang ditemukan dalam studi ini yaitu Media belum bisa mewujudkan ruang publik yang leluasa karena prosentase kepentingan pemilik media masih cenderung tinggi dibandingkan dengan warga; Media hanya dijadikan sebagai komoditas bisnis yang bisa meraup keuntungan dengan jumlah besar; Pemilik media yang juga sebagai konglomerat industri media telah mendapuk dirinya juga dalam dunia perpolitikan. Pemilik media hanya mengomando suara untuk disiarkan dan yang sesuai dengan kepentingannya. Segala bentuk konten yang ada diarahkan untuk bisa memobilisasi pendapat masyarakat untuk memiliki persepsi yang sama seperti kehendak pemilik media. Sehingga konten yang ada sangat tidak proporsional dalam menyajikan data, fakta yang sesungguhnya terjadi.
\end{abstract}

Kata Kunci: Konglomerasi Media, Konvergensi Media, Kebebasan Pers, Kebebasan Berpendapat 


\section{Pendahuluan}

Perkembangan berdirinya berbagai macam industri media yang berada di Indonesia tidak bisa dipisahkan dari sejarah panjang reformasi. Pada masa sebelumnya yaitu era Orde Baru yang dibawah kepemimpinan Presiden Soeharto, industri media dianggap sebagai wadah yang dapat memaparkan keburukan pemerintah sehingga tidak jarang perusahaan pers yang memberitakan tentang pemerintah menemui "ajalnya" hingga berujung pada pencabutan Surat Izin Usaha Penebitan Pers (SIUPP) atau yang lebih dikenal dengan pembredelan. Siapapun dan dalam bentuk apapun media pers yang mengkritisi aturan pemerintah yang ada di rezim Orde Baru, tidak akan memiliki umur yang panjang. Perusahaan persuratkabaran (pers) Majalah Tempo yang dibredel pada tahun 1982 merupakan contoh satu diantara pers yang dibredel. Pada saat itu Majalah Tempo mengkritik tajam pemerintah dengan mengkaitkan partai politik Golongan Karya (Golkar) sebagai kendaraan politiknya. Tidak luput dari pembredelan, pers terbitan Jakarta seperti harian Indonesia Raya, harian Sinar Harapan, tabloid Detik; pers terbitan Surabaya seperti harian Nusantara dan harian Seluruh Berita; dan pers terbitan Bandung yaitu harian Mahasiswa Indonsia mengalami nasib yang sama dengan Majalah Tempo.

Rezim Soeharto bisa dikatakan masa yang sulit bagi para pelaku pers lebih utamanya bagi para wartawan yang ingin mengkritisi kinerja pemerintahan Orde Baru. Pers saat itu masih belum menjadi mitra pemerintah yang mensinergikan masyarakat dengan pemerintah. Kebebasan pers masih dalam belenggu pemerintah yang seakan pers mengharuskan dirinya untuk memberitakan kebaikan pemerintah sesuai dengan Garis-Garis Besar Haluan Negara (GBHN) dan juga Rencana Pembangunan Lima Tahun (Repelita). Hampir tidak terdengar sayup sayup kabar miring tentang pemerintahan Soeharto pada saat itu. Hingga seperti saat ini, masyarakat Indonesia yang pernah hidup di rezim Orde Baru lebih memilih di bawah kepemimpinan Soeharto daripada reformasi karena di atas kertas kemakmuran ekonomi lebih baik di zaman tersebut. Syahri menjelaskan pada era Orde Baru pemerintah sering melakukan intervensi terhadap kebebasan pers. Intervensi yang dilakukan melalui budaya telepon, slogan hubungan positif antara pers dengan pemerintah dan masyarakat serta penguasaan saham penerbitan. Ancaman pembredelan sering menghantui media/pers, bila terjadi pembredelan tanpa melalui proses peradilan (Waluyo, 2014:21).

Kebebasan berpendapat sejatinya diatur di dalam Undang-Undang Dasar 1945 Republik Indonesia amandemen pada pasal 28 yang berbunyi "Kemerdekaan berserikat, dan berkumpul mengeluarkan pikiran dengan lisan dan tulisan dan sebagainya ditetapkan dengan undang-undang" dan pasal $28 \mathrm{E}$ ayat tiga (3), yang berbunyi "Setiap orang berhak atas kebebasan berserikat, berkumpul, dan menyampaikan pendapat". Selain itu juga beberapa aturan yang mengatur tentang kebebasan berpendapat yaitu Piagam Hak Asasi Manusia Indonesia dalam Tap. MPR No. 18 Tahun 1998, pasal 19 yang berbunyi "Setiap orang berhak atas kemerdekaan berserikat berkumpul, dan mengeluarkan pendapat", dan Undang-Undang No. 9 Tahun 1998 tentang Kemerdekaan Menyampaikan Pendapat di Muka Umum. Pers merupakan bagian dari rangkuman opini publik yang berikan ruang sehingga memungkinkan pemerintah untuk melakukan evaluasi atas kinerja yang telah dijalankannya terserbut. Akan sangat bertentangan dengan beberapa dasar hukum tersebut jika kebabasan pers dibungkam dan menuai banyak intervensi yang disertai ancaman. Tidak khayal jika mantan Direktur Lembaga Ekonomi dan Kemasyarakatan Nasional - Lembaga Ilmu Pengetahuan Indonesia (LEKNAS-LIPI), Taufik Abdullah memberikan pandangan di dalam buku yang berjudul "Beberapa Segi Perkembangan Sejarah Pers di Indonesia". Pada bagian kata pengantar, Taufik Abdullah mengungkapkan bahwa pemerintah (Orde Baru) telah menjadikan 
dirinya sebagai pemegang "hegemoni makna" dan "hegemoni wacana." Orde Baru selalu berusaha sekuat tenaga untuk "mendiamkan" dan "mendiskreditkan" segala suara yang dianggap merusak dunia serba konsensus yang telah dikuasainya (Surjomiharjo, 2002).

Masa kelam yang mencekam kebebasan berpendapat pada akhirnya menemukan angin segar saat beralih pada era reformasi. Perusahaan persuratkabaran yang pernah dibredel pun kembali menunjukkan taringnya. Dan mulai bermunculan berbagai macam industri pers yang diawali dengan surat kabar berupa media cetak. Media informasi di Indonesia terus mengalami kemajuan yang pesat dengan berbagai ragam jenis media seperti audio visual berupa televisi, audio yang berupa radio hingga sampai pada puncaknya masyarakat Indonesia dengan mudah menikmati akses informasi tiada batas berupa internet. Poin penting yang menjadi suatu penekanan dibalik bermunculannya banyak media adalah dalam rangka mengawal kebijakan pemerintah. Selain itu juga untuk memberikan kritik kritik terhadap pemerintah sehingga dapat secara simultan mengevaluasi capaian kinerja yang telah dilakukan.

Dalam awal masa kemunculan internet, media ini hanya dapat mengakses berbagai macam informasi berada di dibagian belahan bumi manapun yang dikenal dengan istilah Web 1.0. Hal inilah yang memacu para pelaku media untuk terjun menyelami internet. Hingga pada perkembangannya, internet telah menjelma sebagai sarana interaksi antar manusia baik yang terbatas oleh ruang maupun waktu. Respon balik akan bersifat spontan dan tidak ada penundaaan di dalamnya. Internet inilah yang disebut dengan istilah Web 2.0.

Melalui media internet, masyarakat seakan terhubung satu dengan yang lainnya. Tidak dapat dipungkiri bahwa internet merupakan kebutuhan yang melekat di dalam kehidupan manusia. Tidak hanya bagi kehidupan manusia, keberlangsungan para pelaku industri media saat ini juga memanfaatkan internet sebagai media pancar nirkabel yang hemat biaya dan juga dapat menjangkau lebih luas bergantung pada sinyal internet yang tersedia di dalam suatu daerah. Media persuratkabaran yang dahulunya hanya berupa tulisan yang tertuang di dalam media kertas yang kemudian disebut dengan cara analog kita berubah menjadi era digital yang memberikan lebih banyak inovasi pada media cetak. Utamanya adalah memperkaya informasi dengan lengkap dan bervariasi. Dimulai dari informasi tulisan yang memperbaruinya secara cepat hingga berita berita atau informasi yang dilengkap dengan gambar yang bergerak maupun suara.

Pada hakikatnya bahwa konglomerasi media merupakan persatuan dari berbagai macam media menjadi satu kesatuan yang besar yang kemudian dikendalikan oleh satu orang. Hal ini dapat terjadi karena adanya visi misi yang sama dan juga saham yang digabungkan untuk kemudian dikelola menjadi satu. Selain beberapa hal tersebut, terdapat satu hal yang tidak bisa dipisahkan bahkan menjadi sebuah komponen utama untuk mewadahi dari beberapa media tersebut yaitu media baru yang kemudian disebut internet. Melalui internet, pelaku industri media dapat memainkan kesemua media tersebut dalam satu waktu yang cukup bersamaan. Bahkan saat ini banyak dikenal dengan siaran live streaming baik televisi maupun radio.

Konglomerasi media juga menjadi alat pengontrol atau pengendali banyak informasi dan produk media dengan itu mereka menghasilkan banyak keuntungan. Mereka sangat efisien dalam memproduksi informasi dan menyebarkannya melaui jaringan media seperti televisi, radio dan media cetak dalam satu perusahaan yang mereka miliki (Phillips et al., 2009; Croucher, 2011; Scheufele, 1999). Mengontrol banyak informasi artinya bahwa media secara finasial akan cenderung diuntungkan dan juga pemilik media dengan leluasa menggunakan konglomerasi media tersebut untuk mewakili kepentingannya.

Studi penelitian yang dilakukan oleh Olyvie Bintang Haritajaya dari Universitas Sanata Dharma yang berjudul "Pembredelan Pers di Masa Orde Baru (1966-1998)" menghasilkan 
bahwa Orde Baru membawa dampak kebijakan terhadap pers yang kemudian hal tersebut digunakan sebagai alat untuk membredel pers. Hal tersebut bertujuan untuk menjaga kestabilan politik dan keamanan nasional. Dalam penelitian ini juga mencatat pembredelan yang dilakuan oleh pemerintah berpengaruh langsung kepada perkembangan industri media maupun pers nasional (Haritajaya, 2017).

Pada peralihan masa setelah era Orde Baru menuju ke masa Reformasi, industri media seakan menjamur dengan menyasar pada masing masing kalangan. Wartawan dengan mudahnya mendapatkan berbagai macam informasi untuk kemudian diberitakan kepada seluruh masyarakat. Euforia mahasiswa yang haus akan pembaruan pembaruan kinerja pemerintah seakan tidak menjadi suatu hal yang hanya di angan angan.

Semenjak lahir masa kebebasan pers dan juga berpendapat, pertumbuhan industri media kian pesat dari waktu ke waktu hingga seperti saat ini. Banyak inovasi yang mutakhir yang berkaitan dengan dunia persuratkabaran. Mulai dari menggunakan cara manual atau yang dikenal dengan cara analog hingga digitalisasi yang mampu memberikan efek nyata sehingga para penikmat informasi memperoleh berita langsung dari tempat kejadian. Hal ini tentu dimanfaatkan oleh para pelaku industri media untuk bisa meraup keuntungan dengan modal yang cukup sedikit. Hingga seperti yang saat ini telah terjadi dan menjadi sebuah rahasia umum bahwa berbagai macam media bergabung menjadi satu. Penggabungan beberapa media menjadi satu yang lebih besar ini bukan tanpa tujuan, bahkan bisa dikatakan sebagai pembaruan di era yang serba cyber seperti saat ini.

Gambar tabel 1 berikut ini merupakan contoh konkret dari suatu konglomerasi media. Satu pemilik media akan menamai konglomerasi tersebut menjadi sebuah "group". Artinya bahwa penggabungan dari beberapa media kecil untuk kemudian menjadi satu kesatuan yang besar. Media yang telah tergabung di dalam group tersebut akan memberitakan hal yang sama antara satu dengan yang lainnya. Hal tersebut dapat dikatakan sebagai satu suara dengan mempertahankan informasi sehingga informasi yang diperoleh utuh dan juga tidak simpang siur.

Konglomerasi media sesungguhnya menyimpan kebermanfaatan, salah satunya yaitu efisiensi baik tenaga, pikiran dan juga material. Akan tetapi informasi yang diulas sangat tendensius pada kepentingan pemilik media. Seluruh informasi dibentuk sedemikian rupa sehingga menggiring opini masyarakat untuk mempersepsikan sesuatu hal. Buruknya adalah jika informasi informasi yang disajikan tersebut diberitakan membenarkan yang salah dan menyalahkan yang benar maka informasi yang diberikan tidak lagi memiliki sifat yang fakta. Seluruh media yang tergabung di dalam group konglomerasi tersebut akan seragam memberitakan hal yang sama. Sehingga masyarakat yang mengonsumsi informasi akan terus berpikir bahwa segala hal pemberitaan yang ada merupakan benar adanya.

Sebelum memaparkan beberapa hasil temuan dari berbagai penelitian, penulis terlebih ingin memberikan gambaran tentang media massa. Media massa sangat kental dengan yang kemukakan oleh penemu teori agenda setting yaitu McComb dan Donald Shaw (1972). Teori ini menyatakan bahwa media memiliki kemampuan untuk mentransfer isu untuk mempengaruhi agenda publik. Khalayak akan menganggap suatu isu tersebut penting, karena media menganggap isu tersebut penting (Cottam. et al, 2004:140). Hal inilah yang dimanfaatkan para pemilik group media untuk memobilisasi kepentingannya dengan melakukan intervensi informasi yang sejatinya bersifat netral dan berimbang. Saat ini, terdapat dua belas (12) kelompok media besar mengendalikan hampir semua kanal media di Indonesia, termasuk di dalamnya penyiaran, media cetak dan media online. Mereka adalah MNC Group, Kelompok Kompas Gramedia, Elang Mahkota Teknologi, Visi Media Asia, Grup Jawa Pos, Mahaka Media, CT Group, BeritaSatu Media Holdings, Grup Media, MRA Media, Femina Group dan 
Tabel 1. Konglomerasi Media di Indonesia

\begin{tabular}{|c|c|c|c|c|c|c|c|c|}
\hline \multirow{2}{*}{ Media } & \multirow{2}{*}{ Pemilik } & \multicolumn{2}{|c|}{ Stasiun TV } & \multirow{2}{*}{$\begin{array}{l}\text { Stasiun } \\
\text { Radio }\end{array}$} & \multicolumn{2}{|c|}{ Media Cetak } & \multirow{2}{*}{ On-Line } & \multirow{2}{*}{ Bisnis Lainnya } \\
\hline & & Nasional & Lainny & & $\mathrm{K}$ o r a $\mathrm{n}$ & Tabloid & & \\
\hline $\begin{array}{l}\text { Visi Media } \\
\text { Asia (Viva } \\
\text { Group/Bakrie } \\
\text { \& Brothers) }\end{array}$ & $\begin{array}{c}\text { Anindya } \\
\text { Bakrie, } \\
\text { Aburizal } \\
\text { Bakrie (Pertai } \\
\text { Golkar) }\end{array}$ & $\begin{array}{l}\text { ANTV, } \\
\text { TV One }\end{array}$ & $\begin{array}{c}\text { Channel } \\
\text { [V] }\end{array}$ & 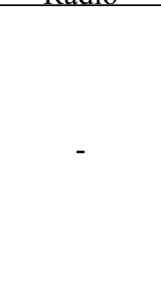 & - & - & $\begin{array}{l}\text { Viva } \\
\text { News }\end{array}$ & $\begin{array}{l}\text { Telekomunikasi, } \\
\text { property, } \\
\text { metal, gas dan } \\
\text { minyak bumi, } \\
\text { agrobisnis, } \\
\text { batubara, } \\
\text { infrastruktur } \\
\text { fisik }\end{array}$ \\
\hline Media Group & $\begin{array}{c}\text { Surya Paloh } \\
\text { (Partai } \\
\text { Nasdem) }\end{array}$ & $\begin{array}{l}\text { Metro } \\
\text { TV }\end{array}$ & - & - & $\begin{array}{c}\text { Media } \\
\text { Indonesia, } \\
\text { Lampung } \\
\text { Post, } \\
\text { Borneo } \\
\text { News }\end{array}$ & - & $\begin{array}{c}\text { Media } \\
\text { Indonesia }\end{array}$ & 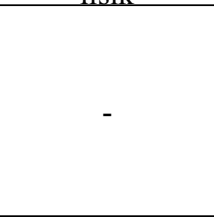 \\
\hline $\begin{array}{c}\text { Media } \\
\text { Nusantara Citra } \\
\text { (MNC) Group }\end{array}$ & $\begin{array}{c}\text { Hary } \\
\text { Tanoesoedibjo } \\
\text { (Partai } \\
\text { Perindo, } \\
\text { dulu Partai } \\
\text { Nasdem lalu } \\
\text { berpeindah ke } \\
\text { Hanura) }\end{array}$ & $\begin{array}{l}\text { RCTI, } \\
\text { Global } \\
\text { TV, } \\
\text { MNC } \\
\text { TV (ex } \\
\text { TPI) }\end{array}$ & $\begin{array}{l}\text { Indovision, } \\
\text { MNC Sky } \\
\text { Vision, } \\
\text { Oke } \\
\text { Vision, } \\
\text { Top TV, } \\
\text { Sun TV, } \\
\text { Network } \\
\text { (13 TV } \\
\text { lokal) }\end{array}$ & $\begin{array}{c}\text { Trijaya } \\
\text { FM, Radio } \\
\text { Dangdut, } \\
\text { ARH } \\
\text { Global } \\
\text { Radio }\end{array}$ & $\begin{array}{l}\text { Seputar } \\
\text { Indonesia } \\
\text { (Koran } \\
\text { Sindo) }\end{array}$ & $\begin{array}{l}\text { High } \\
\text { End } \\
\text { Genie, } \\
\text { Mom \& } \\
\text { Kiddie } \\
\text { Tabloid }\end{array}$ & Okezone & $\begin{array}{l}\text { IT, produksi } \\
\text { dan distribusi } \\
\text { konten, talent } \\
\text { management, } \\
\text { otomobil }\end{array}$ \\
\hline $\begin{array}{c}\text { Corporation/CT } \\
\text { Group (Para } \\
\text { Group) }\end{array}$ & $\begin{array}{c}\text { Chairul } \\
\text { Tanjung } \\
\text { (Partai } \\
\text { Demokrat) }\end{array}$ & $\begin{array}{l}\text { Trans } \\
\text { TV, } \\
\text { Trans } 7\end{array}$ & $\begin{array}{l}\text { Telkom } \\
\text { Vision }\end{array}$ & - & - & - & $\begin{array}{l}\text { Detik } \\
\text { online }\end{array}$ & $\begin{array}{l}\text { Bank, modal, } \\
\text { asuransi, studio } \\
\text { trans, resort, } \\
\text { retail, bioskop }\end{array}$ \\
\hline $\begin{array}{c}\text { Jawa Pos } \\
\text { Group }\end{array}$ & $\begin{array}{l}\text { Dahlan Iskan } \\
\text { (Menteri } \\
\text { Badan Usaha } \\
\text { Milik Negara- } \\
\text { BUMN-Susilo } \\
\text { Bambang } \\
\text { Yudoyono } \\
\text { Jilid II, Partai } \\
\text { Demokrat) }\end{array}$ & - & $\begin{array}{c}\text { JTV, } \\
\text { Batam } \\
\text { TV, Riau } \\
\text { TV, Fajar } \\
\text { TV, dan } \\
\text { lainnya } \\
\text { (total 12 } \\
\text { TV lokal) }\end{array}$ & $\begin{array}{c}\text { Fajar FM } \\
\text { (Makassar) }\end{array}$ & $\begin{array}{l}\text { Jawa Pos, } \\
\text { Indo Pos, } \\
\text { Rakyat } \\
\text { Merdeka, } \\
\text { Radar, } \\
\text { dan lain- } \\
\text { lain (total } \\
\text { 151) }\end{array}$ & $\begin{array}{c}\text { Mentari, } \\
\text { Liberty, } \\
11 \\
\text { tabloid }\end{array}$ & $\begin{array}{c}\text { Jawa Pos } \\
\text { Digital } \\
\text { Edition }\end{array}$ & $\begin{array}{l}\text { Biro Travel, } \\
\text { power plant }\end{array}$ \\
\hline
\end{tabular}

Sumber: Lim, 2011

Tempo Inti Media. Grup MNC memiliki tiga kanal televisi free-to-air - jumlah terbanyak yang dimiliki oleh grup media - juga 20 jaringan televisi lokal dan 22 jaringan radio di bawah anak perusahaan mereka, Sindo Radio. Grup Jawa Pos memiliki 171 perusahaan media cetak, termasuk di dalamnya Radar Grup. KOMPAS, surat kabar paling berpengaruh di Indonesia, telah mengekspansi jaringannya dengan mendirikan penyedia konten yaitu KompasTV, di samping 12 penyiaran radio di bawah anak perusahaan mereka Radio Sonora, dan 89 perusahaan media cetak lainnya. Visi Media Asia telah berkembang menjadi kelompok media yang kuat dengan dua saluran televisi teresterial (ANTV dan tvOne) serta media online yang berkembang dengan pesat vivanews.com. Sebuah perusahaan media di bawah Grup Lippo yakni Berita Satu Media Holding, telah mendirikan Internet Protocol Television (IPTV) BeritaSatuTV, kanal media online beritasatu.com dan juga memiliki sejumlah surat kabar dan majalah (Nugroho, Yanuar. et al, 2012). Hal tersebut memberikan suatu pandangan di dalam pemikiran kita bahwa betapa berkuasanya pemiliki industri media yang menjalankan praktik konglomerasi untuk 
mengendalikan segala bentuk pemberitaan maupun informasi.

Selain keterkaitannya dalam membentuk sebuah agenda setting, media juga memiliki fungsi sebagaimana yang dikemukakan oleh Norris (2000), yaitu: 1) sebagai forum warga (civic forum); 2) sebagai pengawas pemerintah atau lembaga lembaga publik (watch-dog); dan 3) sebagai agen mobilisasi dukungan warga terhadap suatu posisi politis (Putra, 2004:135). Norris memberikan gambaran yang cukup jelas untuk kemudia dapat dikaitkan dengan konglomerasi media seperti saat ini terjadi. Dari pernyataan tersebut dapat diuraikan satu persatu.

Pertama, media sebagai forum warga. Media yang baik akan senantiasa lebih mengedepankan kepentingan masyarakat daripada kepentingan pribadi pemilik media. Forum warga yang dimaksud adalah memberikan wadah kepada masyarakat khususnya yang terjadi di Indonesia untuk berdiskusi permasalahan di suatu negara yang kemudian mencari solusi bersama. Sejatinya, media adalah ruang publik dalam konsep kepublikan segala hal yang diperbincangkan adalah permasalahan publik. Kecenderungan saat ini semua media banyak menyajikan informasi maupun berita yang "dibutuhkan" oleh pemilik media. Media tidak lagi menghadirkan hal hal yang diinginkan oleh masyarakat dan ironisnya hal ini terjadi secara terorganisir dengan baik. Sebuah studi penelitian yang telah dilakukan oleh Karman yang berjudul "Media dan Kepentingan Publik: Praktik Media Massa Menurut Teori Normatif" menghasilkan bahwa pluralitas dan kepemilikan (plurality of ownership) media sulit untuk tidak didominasi kelompok kepentingan tertentu. Pengusaha media cenderung meningkatkan akumulasi modal sehingga cenderung oligarkis atau monopoli (konglomerasi media). Sehingga konten-konten yang disuguhkan beberapa media massa mainstream kerap ditunggangi berbagai macam kepentingan pemiliknya. Dalam penelitian ini juga menyoroti tentang contoh pemberitaan konflik di Ambon dulu, atau pemberitaan media massa tentang kepala daerah yang ikut mendemo pemerintah. Sinetron TV pun didominasi tentang kehidupan kaum metropolisborjuis dengan tema yang dapat dikatakan sama antara satu media dengan media lainnya (gejala konsonansi). Keanekaragaman masyarakat, potret monografi kebhinekaan Indonesia dalam hal daerah, politik, agama, etnik, budaya, dan sebagainya mustahil dicapai oleh media massa. Yang muncul adalah media memiliki kecenderungan terhadap daerah, agama tertentu (Karman, 2013). Dari hasil sorotan paparan penelitian di atas dapat menimbulkan sebuah pertanyaan, Mengapa media yang berfungsi sebagai forum warga belum terwujud padahal Indonesia telah lama berada di dalam era reformasi dan juga seperti saat ini terjadi yaitu praktik konglomerasi media?

Kedua, media sebagai pengawas pemerintah atau lembaga lembaga publik (watch-dog). Nampaknya media yang memiliki fungsi sebagai pengawal kebijakan pemerintah dan juga sebagai pengawas pemerintah ini belum bisa dikatakan optimal. Hal ini terjadi karena para pemilik media yang berkuasa saat ini dan yang terjadi di Indonesia duduk dikursi kursi parlemen. Sehingga bisa dikatakan media hanya digunakan untuk memberikan pemberitaan "baik" dan seakan menutupi kebobrokan pemerintah maupun lembaga lembaga publik lainnya. Tak khayal bahwa praktik konglomerasi yang tengah berlangsung seperti saat ini adalah representasi dari media yang ada di masa Orde Baru. Karena memang masing masing group media mengklaim dirinya baik dan lebih unggul diantara yang lainnya. Studi penelitian yang dilakukan oleh Aria Aditya Setiawan yang berjudul "Peran Media Massa dalam Meningkatkan Kualitas Kepemerintahan Lokal Berbasis Human Security di Kota Jayapura" menyatakan bahwa media massa yang ada belum mampu berkoordinasi dengan baik walaupun telah melibatkan local governance dan juga tidak cukup hanya melakukan pendekatan hukum dan militer saja, namun perlu mengintegrasikan berbagai pendekatan lainnya dan melibatkan semua komponen masyarakat (Setiawan, 2013). 
Dari hasil tersebut memberikan gambaran kepada kita masyarakat menjadi modal penentu bagi keberlangsungan pemerintahan. Termasuk juga di dalamnya itu sebagai pengawas pemerintahan. Dengan menghadirkan beragam konten yang bersifat publik, media diharapkan mampu untuk mengakomodir suara masyarakat sehingga kritikan kritikan masyarakat terhadap kinerja pemerintah bisa langsung didengar.

Kecenderungan media saat ini ditengah praktik konglomerasi yang terus merajalela kurang bisa untuk menghubungkan suara rakyat dalam hal sinergitas pengawasan terhadap pemerintah maupun terhadap lembaga lembaga publik. Media lebih intens pada kepentingan sendiri termasuk mencari keuntungan dengan jumlah prosentase yang cukup besar. Media menjelma menjadi wadah "pebisnis" yang meraup keuntungan dengan memanfaatkan fasilitas yang ada. Dari permasalah tersebut, terdapat satu studi penelitian yang dilakukan oleh Hartinah Sanusi, dkk dengan judul "Manajemen Media Televisi Fajar TV: Antara Bisnis dan Idealisme" memaparkan hasil bahwa aktivitas-aktivitas manajemen media terkait isu-isu dorongan pasar, isu-isu kepentingan publik, dan isu-isu jurnalisme penyiaran televisi menunjukkan kecenderungan kuat pada aktivitas media yang berorientasi bisnis (market oriented). Hal ini, tidak lepas dari pengaruh-pengaruh hubungan eksternal dan internal lingkungan organisasi media Fajar TV, terutama hubungan dengan pemilik (owner), pengiklan (advertiser), dan sponsor. Manajemen Fajar TV cenderung lebih banyak menggunakan rasionalitas ekonomi dalam setiap kebijakannya. Manajemen redaksi tidak hanya melihat soal isu liputan atau peristiwa yang menarik perhatian audiens dan pengiklan saja, tapi juga pada soal pembatasan biaya atau cost liputan. Lebih lanjut, dalam penelitian ini menyoroti tentang konten televisi yang tidak proporsional. Dengan total 18 jam siaran per hari, manajemen Fajar TV mengalokasikan 11 jam untuk program Home Shopping, dan sisa durasi yang 6 jam harus dibagi dengan program informasi dan hiburan lainnya. Dengan pendapatan iklan rata-rata yang masih sangat berfluktuatif sekitar 200 juta IDR hingga 400 juta IDR per bulan, manajemen Fajar TV masih harus berupaya keras untuk bisa menutupi operasional cost yang mencapai sekitar 500 juta IDR per bulan dengan fixed cost tertinggi untuk gaji karyawan 94 juta IDR per bulan (Sanusi, Hartinah. et al). Seperti yang dijelaskan pada tabel 1 di bagian sebelumnya, nampak bahwa Fajar TV yang merupakan televisi lokal di Provinsi Sulawesi Selatan tergabung dalam group Jawa Pos yang dimiliki oleh Dahlan Iskan. Secara konglomerasi, Jawa Pos group ini memiliki aset yang cukup besar dimulai dari media televisi hingga media cetak berbasis online hanya saja tidak memiliki televisi nasional. Jika dianalogikan bahwa semakin banyak media yang tergabung maka pendapat pun juga semakin banyak dan bahkan dapat saling menutupi anggaran satu dengan yang lainnya. Hal inilah yang kemudian dijadikan oleh pemilik media sebagai "kambing hitam" dengan alasan anggaran pemasukan yang tidak mencukupi. Sehingga kemudian memangkas berbagai konten program yang mewadahi suara masyarakat dan cenderung pada konten bisnis berupa iklan iklan. Beberapa contoh pemaparan kongkrit hasil penelitian di atas kemudian dapat diambil sebuah pertanyaan yang terkait dengan penggabungan media atau yang disebut dengan konglomerasi media, Mengapa media yang berfungsi sebagai pengawas pemerintah atau lembaga lembaga publik (watch-dog) masih cenderung rendah dan bahkan lebih mengedepankan kepentingan berbisnisnya?

Ketiga, sebagai agen mobilisasi dukungan warga terhadap suatu posisi politis. Fungsi yang terakhir ini merupakan fungsi media yang cukup popular terjadi di Indonesia khususnya di tengah konglomerasi seperti saat ini. Media hanya digunakan sebagai "alat" untuk memobilisasi kepentingan kepentingan politik praktis oleh pemilik media. Para pemilik media tidak hanya berpikir bagaimana memimpin dan mengelola perusahaan industri media, lebih dari itu para pemilik media konglomerasi berpikir 
bagaimana dirinya bisa berkuasa. Dalam pengertian bebasnya, politik merupakan suatu hal yang dilakukan oleh seseorang untuk bisa mendapatkan kekuasaan. Artinyabahwa politikus adalah orang yang melakukan bermacam macam cara untuk bisa berkuasa dan menjadi penguasa. Seperti pada tahun 2014 yang merupakan tahun politik bagi bangsa Indonesia karena di tahun itu pemilihan presiden akan dihelat. Studi penelitian yang dilakukan oleh Alvina Malvi tahun 2014 yang berjudul "Representasi Citra Politik Iklan Hanura WIN-HT Bersih Peduli Tegas di RCTI" menyatakan hasil bahwa iklan yang didalamnya termuat Hary Tanoesoedibjo yang pada saat itu menjadi Cawapres 2014 dari partai HANURA ditayangkan di televisi miliknya karena dalam hal ini Hary Tanoesoedibjo memiliki kekuatan tiga media yang sukses di Indonesia yang kemudian berhak memproduksi dan menayangkan iklan sesuai waktu yang dia inginkan termasuk juga pada waktu waktu yang banyak dilihat oleh audiens (prime time). Dalam penelitian ini juga menyoroti berkaitan dengan citra politik yang dibangun dan ditampilkan dalam iklan yaitu wish image dimana pihak HANURA ingin memperkenalkan atau mempopulerkan WIN dan HT sebagai satu pasangan yang memiliki sifat bersih peduli tegas (Malvi, 2014). Dari pemaparan hasil penelitian tersebut tergambar bahwa media memegang peranan penting dalam memobilisasi kepentingan politik sehingga pesan yang disampaikan akan berdampak langsung kepada masyarakat. Selain itu juga, media digunakan sebagai "alat" pelicin yang digunakan pemilik dalam hal ini untuk bersosialisasi dengan mudah karena masih dalam jangkauan kepemilikan.

Mediapadadasarnyamemilikitugasuntuk memberikan edukasi kepada masyarakat yang berkaitan dengan demokrasi. Akan tetapi dalam hal ini, media yang ada "dimanfaatkan" oleh pemilik media itu sendiri untuk berkampanye politik. Sehingga konten yang ada mengalami gradasi tugas sebagaimana harusnya. Penelitian lain yang dilakukan oleh Dedi Fahrudin dengan judul "Konglomerasi Media: Studi Ekonomi
Politik Terhadap Media Group" menghasilkan bahwa media group yang dipimpin Surya Paloh mengalami proses konglomerasi baik secara vertikal maupun horizontal. Secara vertikal media group memiliki perusahaan media, seperti Metro TV, Media Indonesia, Lampung Pos. Sedangkan horizontalnya media group memiliki usaha lain yang tidak berhubungan dengan usaha media seperti hotel, catering, dan pertambangan. Media dijadikan alat politik atau publisitas politik (political publicity) oleh pemiliknya untuk memperkenalkan partai Nasdem dari berbagai sisi, mulai dari visi dan misi hingga kegiatan partai. Media juga digunakan untuk meliput dan memberitakan apa dan bagaimana aktifitas politik pemilik media maupun aktifitas partainya (Fahrudin, 2013). Dari beberapa sorotan penelitian di atas lengkaplah sudah bahwa media tidak lebih hanya sebagai alat yang digunakan pemilik dalam rangka meraup dukungan warga terhadap suatu posisi politis. Realitas yang sangat bertolak belakang dengan tugas pokok dari sebuah media. Akan tetapi tidak bisa dipungkiri bahwa hal tersebut sangat bebas terjadi karena ketidak kuasaan untuk menghalanginya. Terlebih pada saat ini yang sangat gencar praktik konglomerasi media. Hal tersebut akan memperpanjang deretan permasalahan yang muncul terkait dengan industri media. Bukan hanya satu media yang dijadikan sebagai "alat" melainkan group yang tergabung di dalamnya. Sehingga pemberitaan atau konten yang tersaji akan lebih condong sesuai dengan permintaan sang pemilik. Muncul sebuah pertanyaan, Mengapa media yang berfungsi sebagai agen mobilisasi dukungan warga terhadap suatu posisi politis tidak bisa menyeimbangkan konten dan cenderung hanya terfokus pada yang pemilik minta?

\section{Metode Penelitian}

Penelitian ini menggunakan metode kulitatif dengan pendekatan utama yaitu MetaSistesis sebagai metode systematic review kualitatif. Dalam metode ini ada beberapa langkah pendekatan untuk bisa melakukan 
sebuah penelitian. Adapun langkah-langkah systematic review kualitatif diuraikan sebagai berikut (Francis \& Baldesari, 2006):

1. Memformulasikan pertanyaan penelitian (formulating the review question);

2. Melakukan pencarian literatur systematic review (conducting a systematic literature search);

3. Melakukan skrining dan seleksi artikel penelitian yang cocok (screening and selecting appropriate research articles);

4. Melakukan analisis dan sintesis temuantemuan kualitatif (analyzing and synthesizing qualitative findings);

5. Memberlakukan kendali mutu (maintaining quality control);

6. Menyusun laporan akhir (presenting findings).

Dalam melakukan meta-sintesis (sintesis data kualitatif) terdapat 2 (dua) pendekatan, yakni meta agregasi (meta-aggregation) dan meta-etnografi (meta-ethnography). Pada meta agregasi, sintesis bertujuan untuk menjawab pertanyaan penelitian (review question) dengan cara merangkum berbagai hasil penelitian (summarizing). Sementara, meta etnografi, sintesis bertujuan untuk mengembangkan teori baru (new theory) dalam rangka melengkapi teori yang sudah ada (Lewin, 2008).

Teknologi merupakan alat yang paling menentukan kualitas suatu hal untuk kemudian dapat dinikmati, termasuk dalam hal ini teknologi yang digunakan industri media dalam memproduksi sebuah konten. Teknologi akan semakin canggih seiring dengan perkembangan dan kemajuan zaman. Terlihat seperti yang saat ini tengah terjadi, seluruh aspek kehidupan manusia tidak luput dari sentuhan berbagai macam teknologi. Tidak terkecuali dalam aspek telekomunikasi yang kemudian disebut sebagai Information and Communication Technology (ICT). Semua hal yang berbau ICT telah menjelma menjadi bentuk bentuk yang digital yang pada awal mulanya hanya analog (manual). Perkembangan teknologi inilah yang membuat manusia terus memperbarui telekomunikasinya terlebih pada industri media yang mempersyaratkan penggunaan peralatan yang canggih.

Zaman yang semakin berkembang pesat memaksa para pelaku industri media untuk bisa tetap survive agar mimpi buruk kebangkrutan tidak terjadi. Perlu adanya strategi tingkat tinggi untuk menyesuaikan dengan pesatnya kemajuan zaman dan juga teknologi. Selain menjalankan fungsinya sebagai media massa, industri media juga menjalankan roda bisnis yang tentu memiliki cara tersendiri dalam merancang strategi. Strategi bisnis bisa berupa perluasan geografis, diversifikasi, akuisisi, pengembangan produk, penetrasi pasar, rasionalisasi karyawan, divestasi, likuidasi, dan joint venture (David, 2004:15). Bentuk bentuk strategi bisnis tersebut kemudian diwujudkan dalam penggabungan media (merger media) yang biasa disebut dengan konglomerasi media.

Konglomerasi media sangat erat kaitannya dengan konvergensi yang di dalamnya mengubah cara pandang kuno yang mengandalkan teknologi sederhana. Konvergensi media tidak dapat diartikan secara gamblang. Akan tetapi substansi dari konvergensi media ini yaitu seperti layaknya suatu perpaduan suara yang saling mengisi dan menambahkan pada ruang yang kosong. Penambahan inilah yang selanjutnya merubah konten tradisional kepada suatu konsep modern. Tidak dapat dipungkiri bahwa yang saat ini terjadi media layar menjadi pengganti media kertas dalam menemukan berbagai macam informasi. Segala hal yang menggunakan analog ketika masuk ke dalam media layar akan berubah menjadi digital. Hal inilah yang dimaksud dengan penambahan yang terjadi pada konvergensi media. Saling melengkapi satu diantara yang lainnya, televisi dilengkapi dengan media cetak dan online. Begitu juga halnya dengan media online yang dapat mengakses media televisi di dalamnya. Konvergensi media mendorong untuk terus berinovasi pada pembaruan platform. Manusia akan cenderung dipermudah dengan segala kanal akses. Informasi yang dihasilkannya pun akan 
sangat jauh berbeda karena satu informasi yang disajikan akan berkolaborasi dengan beragam media, seperti media visual, audio, audio visual, cetak, dan online. Sehingga, informasi yang diberikan tidak terlalu monoton dan dapat dinikmati dengan lebih puas. Disinilah letak kecanggihan teknologi yang dihasilkan oleh industri media yang saat ini tengah berlangsung.

Horst Pirker, Ketua Dewan Styria Medien (Austria), dalam pidatonya di International Newsmedia Marketing Association (INMA) Konferensi Outlook Eropa, yang ditutup di Wina 2008 mengatakan kepada audiens bagaimana masa depan surat kabar bergantung pada multi-media, multi-channel, dan multiplatform. Namun, pidatonya berawal dengan kabar buruk bagi industri. Di Jerman, peredaran surat kabar harian telah mengalami penurunan sejak tahun 1991. Di AS, obligasi tersebut jatuh pada tahun 1898. Pangsa pasar juga menurun dengan cepat. Tapi dia memang punya kabar baik. Banyak surat kabar melawan tren tersebut dengan mengadopsi lingkungan media yang terus berubah. Perkembangan baru muncul yang mempengaruhi masa depan koran. Ini termasuk digitalisasi e-paper, broadband, hypermedium internet, weblog, games dll. Ada juga pendekatan multimedia atau strategi MMM - multimedia, multichannel, dan multiplatform. Multimedia menyediakan pembaca tidak hanya dengan teks dan foto, tapi juga suara dan video. Multichannel berarti menggunakan banyak saluran distribusi yang berbeda (kabel, satelit, GRPS, WiFi, dll). Sementara multiplatform menggunakan semua platform yang tersedia (kertas, PC, perangkat Mobile, layar publik, dll.) Pirker meyakini bahwa surat kabar memiliki masa depan yang cerah. Karena ada banyak model yang bisa berhasil di atas kertas, tapi juga model yang lebih banyak untuk sukses secara online. Tujuan bagi perusahaan media adalah bagaimana menghasilkan keuntungan dari inisiatif online, dan inilah tantangan nyata bagi industri ini (N\&M NEWSPAPER\&MAGAZINES, 2008:8).

Dari pemaparan Horst Pirker memberikan gambaran yang cukup gamblang bahwa industri media akan semakin baju dan berkembang dengan pesat. Dengan menggunakan strategi 3M (multimedia, multichannel, dan multiplatform), industri media mampu mengepakkan sayap sejauh yang mereka kehendaki. Sangat efektif dan efisien untuk dilakukan dan juga meminimalisir dana yang dibutuhkan. Selain itu juga mengoptimalkan internet yang sebagai media penghantarannya. Hal ini merupakan sebuah terobosan baru di dunia media abad 21 yang tidak pernah terpikirkan pada abad sebelumnya. Hanya dengan mengandalkan pancaran sinyal internet yang bisa didapatkan melalui LAN (Local Area Network) maupun Wi-Fi (Wireless-Fidelity), para pengguna media dan audiens bisa dengan leluasa mengakses informasi dimanapun, kapanpun, dan juga dalam kondisi apapun.

\section{Hasil dan Pembahasan \\ Kebebasan Pers}

Semenjak bergulirnya era reformasi yang dimotori oleh presiden BJ. Habibie, pers mulai tumbuh dan menjamur seperti layaknya seekor harimau yang tengah kelaparan untuk segera mencari mangsa. Nampaknya era reformasi menjadi pintu gerbang yang terbuka lebar dalam industri pers untuk mengembangkan seni jurnalistiknya. Terlebih padakaumyang bermodal terus berlomba lomba untuk mendirikan industri media. Dicabutnya Permenpen No.01/Per/ Menpen/1984 tentang SIUPP yang kemudian diganti dengan SK No.132/1998 membolehkan siapa pun memeroleh SIUPP dengan hanya mengisi formulir permohonan, akte pendirian perusahaan, dan susunan pengasuh penerbitan pers. Dengan memproduksiberbagaimacam hasil pers dan dipersenjatai peralatan yang canggih, industri media terus menerus melakukan ekspansi besar besaran utamanya pada tataran konten. Pers yang semula tidak bisa memberikan lebih informasi karena "dibungkam" oleh pemerintah, saat ini seakan terobati dan menjadi pelepas dahaga para pencari informasi. Masyarakat pun turut hanyut dalam gegap gempita pertumbuhan pers yang semakin baik dari waktu ke waktu. 
Kebebasan pers menjamin keterbukaan informasi dan keberagaman opini. Hal ini diatur dalam Undang-Undang No.40 tahun 1999 tentang Pers yang dimana pada pasal 4 ayat 3 dan ayat 4 . Adapun bunyi dari ayat tiga (3) yaitu, untuk menjamin kemerdekaan pers, pers nasional mempunyai hak mencari, memperoleh, dan menyebarluaskan gagasan dan informasi. Sedangkan ayat empat (4) berbunyi yaitu, dalam mempertanggungjawabkan pemberitaan di depan hukum, wartawan mempunyai Hak Tolak. Jelas terlihat dalam Undang-Undang tersebut menjamin kebebasan pers dan juga hak dalam beropini. Segala macam informasi akan legal dan dapat diberitakan selama hal tersebut dalam koridor yang benar dan juga sesuai dengan SOP (Standard Opersional Procedure). Jaminan inilah yang kemudian dimanfaatkan oleh sejumlah orang dalam melindungi hak siarannya.

Pada era Orde Baru, industri media sangat dikendalikan oleh pemerintah yang dalam hal ini dibawah departemen penerangan. Tidak ada kebebasan berpendapat di dalamnya. Seluruh industri media mendambakan pers yang otonomi dan juga bebas dalam memberitakan apapun halnya. Akan tetapi setelah perubahan zaman pun hal yang demikian tetap terjadi. Seluruh wartawan yang bekerja di dalam sebuah industri media harus tunduk dan patuh terhadap pemilik dari media tersebut. Kondisi yang cukup miris ketika penggabungan beberapa industri media menjadi sebuah group yang dipimpin oleh satu orang. Seluruh group yang tergabung di dalamnya berada pada satu komando yang sama. Hal inilah yang menjadikan kurangnya bebas dalam menyiarkan informasi. Dengan kekuasaan pemilik group media tersebut mengarahkan segala macam berita yang dapat menguntungkan dirinya beserta perusahaan yang dimilikinya. Realitas inilah yang disebut dengan konglomerasi media. Dengan dalih kebebasan pers, sang pemilik media membentuk sebuah opini dikalangan masyarakat melalui pemberitaan yang beredar.

Sebuah studi penelitian yang dilakukan oleh Joko Martono pada 2014 silam dengan judul "Kebebasan Pers di Indonesia Pada Era Reformasi dan Ekonomi Politik Media" mengahasilkan suatu fakta bahwa kebebasan pers di era reformasi ternyata telah didistorsi oleh kalangan pengelola perusahaan media, terutama media massa swasta/komersial. Kebebasan pers yang telah dijamin melalui regulasi cenderung ditafsirkan sepihak, hanya untuk memenuhi kepentingan yang berorientasi profit. Peliputan terhadap suatu peristiwa seperti bencana alam pada taraf mikro telah dilakukan komodifikasi isi pesan cenderung bertujuan untuk meraup keuntungan perusahaan media yang bersangkutan. Konsep yang digunakan oleh media dalam mengoperasionalisasikan aktivitasnya berpendekatan pada ekonomi politik sebagai sebuah strategi bisnis. Implikasi atas praktik kebebasan pers yang sering menimbulkan efek pesan maupun dampak dampak berupa benturan kepentingan antara pengelola media, penguasa, dan kepentingan warga/ khalayak luas merupakan konsekuensi yang harus ditanggung. Ruang publik yang seharusnya merupakan milik bersama, dimanfaatkan bersama, namun pada kenyataannya cenderung dimonopoli oleh kepentingan perusahaan (industri) media. Ongkos atau biayanya sosialnya sangat tinggi bilamana efek atas pemberitaan media terhadap si penerima pesan ini sudah mencapai taraf perilaku (behavior), seperti pemberitaan tayangan Silet (RCTI) telah menyebabkan terjadinya eksodus 550 warga/korban bencana meletusnya Gunung Merapi yang berada di barak pengungsian menuju lokasi lain yang lebih aman. Demikian halnya pemberitaan bencana banjir di Jakarta yang disajikan secara "berlebihan" dalam bingkai komodifikasi isi pesan telah mengundang kecemasan maupun kekesalan warga, termasuk munculnya respons atas pesan atau pemberitaan yang dinilai kurang proporsional.

Dalam penelitian ini juga menyoroti mengenai ketidak siapan masyarakat dalam menghadapi paparan media yang tersaji secara beragam. Sehingga memungkinkan masyrakat 
untuk menafsirkan sesuai dengan kemampuan dan pemahaman masing masing. Perlu adanya wawasan pentingnya literasi media dengan harapan bahwa seluruh lapisan masyrakat memahami segala bentuk pemberitaan atau informasi yang didalamnya memuat beragam kepentingan dari pemilik industri media. Adapun dari pentingnya literasi media di era kekinian bagi khalayak luas antara lain: 1) agar terbentuk kecakapan dalam menghadapi terpaan pesan media massa; 2) lebih menjadikan mereka sebagai audiens yang aktif ketika menerima terpaan pesan dari media, terutama dari medium televisi, sehingga akan dapat memilah dan memilih mana pesan/informasi yang bermanfaat atau tidak bagi diri atau kelompoknya (Martono, 2014).

Penelitian Joko Martono membuka wawasan kita bahwa konten media yang tersaji syarat akan kepentingan. Tidak bisa dipungkiri konglomerasi media menjadikan seluruh media tidak bisa berimbang dalam menyajikan berita. Semua yang tersaji merupakan berita yang memihak pada pemilik media. Media hanya dijadikan boneka kecil yang dapat dimainkan dengan leluasa oleh pemiliknya. Terlebih pada pemilik media yang menginginkan posisi lebih "berkuasa" di dalam ranah politik. Pada bagian ini, penulis mencoba menjawab beberapa pertanyaan yang telah dirumuskan pada bagian sebelumnya berkaitan dengan konglomerasi media dan kebebasan pers. Adapun pertanyaan tersebut adalah: 1) Mengapa media yang berfungsi sebagai forum warga belum terwujud padahal Indonesia telah lama berada di dalam era reformasi dan juga seperti saat ini terjadi yaitu praktik konglomerasi media?. 2) Mengapa media yang berfungsi sebagai pengawas pemerintah atau lembaga lembaga publik (watchdog) masih cenderung rendah dan bahkan lebih mengedepankan kepentingan berbisnisnya?. 3) Mengapa media yang berfungsi sebagai agen mobilisasi dukungan warga terhadap suatu posisi politis tidak bisa menyeimbangkan konten dan cenderung hanya terfokus pada yang pemilik minta?
Pertama, Mengapa media yang berfungsi sebagai forum warga belum terwujud padahal Indonesia telah lama berada di dalam era reformasi dan juga seperti saat ini terjadi yaitu praktik konglomerasi media?

Sebagai institusi kontrol sosial, media belum mampu menyediakan penuh ruang publik. Kenyataan lain bahwa media hanya digunakan sebagai "alat" atau yang disebut sebagai partner pemilik dalam kepentingannya. Tahun 2018 merupakan tahun politik bagi kontestasi pemilihan gubernur secara serentak dibeberapa wilayah di Indonesia. Beberapa pemilik media yang notabene turut serta dalam dunia perpolitikan terus menerus menghujani media yang dimilikinya untuk bersosialisasi partai yang dimiliki. Dimulai dari partai Nasional Demokrat (NasDem), partai Golongan Karya (Golkar), dan tidak ketinggalan juga yaitu partai baru yang digagas oleh Hary Tanoesoedibjo yaitu PERINDO. Hary Tanoesoedibjo yang merupakan pemilik dari MNC Group memperalat media yang dimilikinya untuk terus gencar beriklan PERINDO berupa mars PERINDO. Tercatat bahwa data dari Adstensity-sebuah platform yang menghitung dan menganalisa data iklan di televisi-selama kurun waktu tiga bulan terakhir, terhitung dari November 2015 hingga Januari 2016, iklan partai Perindo di MNC Group mencapai 1918 kali. Rincian iklan tersebut yakni RCTI (648 kali), MNC TV (630 kali) dan Global TV (640 kali). Sedangkan nilai yang digelontorkan untuk memasang iklan tersebut berkisar 132 milliar IDR (Aqwam Fiazmi Hanifan, Tirto.id 2016). "Rudal politik" yang diluncurkan oleh Hary Tanoesoedibjo bukan tanpa tujuan dibalik semua itu bertujuan untuk mendulang suara pada partainya untuk kemudian dirinya dapat mengikuti kontestasi pada pemilihan presiden di tahun 2019. Dalam survei lain yang dilakukan pada 16 Februari 2018 oleh adstensity.com merangkum selama 7 hari (10 Februari 2018 - 16 Februari 2018) mencatat iklan partai PERINDO yang ditayangkan oleh MNC Group yakni Global TV (116 kali) dengan total durasi 4,880 jam, 
MNC TV (120 kali) dengan total durasi 5,000 jam, dan RCTI (126 kali) dengan total durasi 5,180 jam. Jika dihitung secara matematis dalam satu hari iklan partai PERINDO yang tayang di Global TV (41,8 menit), MNC TV (42,9 menit) dan RCTI (44,4 menit). Sedangkan kisaran total biaya yang digelontor untuk "beriklan" di medianya sendiri sebesar 22.248.280.000 IDR dengan rincian yakni Global TV (5,055 miliar IDR), MNC TV (8.203.340.000 IDR), dan RCTI (8.989.940.000 IDR) (adstensity.com - 16 Februari 2018). Jumlah yang sangat besar dengan waktu yang tidak lama. Dalam melancarkan aksinya, pemilik MNC Group ini menempatkan iklan partai PERINDO pada tayangan tayangan yang memiliki rating tinggi dan juga di jamjam prime time. Pada survei yang dilakukan Litbang Kompas mencatat bahwa RCTI yang semenjak sore hingga malam hari menayangkan sinetron, sementara pada pagi hingga siang hari menyuguhkan infotainment dan musik. Hal ini terbukti dari survei yang dilakukan Komisi Penyiaran Indonesia (KPI) dan Ikatan Sarjana Komunikasi Indonesia (ISKI) serta sembilan perguruan tinggi di sembilan kota di Indonesia pada pertengahan 2015 menunjukkan, indeks kualitas program siaran 15 televisi di Indonesia hanya 3,27 atau masih di bawah standar ketentuan KPI, yakni 4,0. Survei KPI yang dilakukan pada September-Oktober 2015 menunjukkan, indeks kualitas tiga program siaran, yaitu infotainment, sinetron/film/FTV, dan variety show di bawah 3 , masih di bawah standar nilai minimal 4. Skor program infotainment hanya 2,56, sinetron/ film/FTV 2,84, dan variety show 2,96. Padahal, program-program tayangan yang kualitasnya rendah tersebut justru mendominasi layar kaca pada rentang waktu utama (prime time) (Dwi Erianto, Litbang Kompas 2016). Penerapan yang tidak berimbang antara implementasi hiburan dengan penyajian informasi serta ditambah dengan iklan partai. Ruang publik yang ada di dalam media massa semakin tereduksi dengan hal hal yang tidak seberapa berpengaruh.

Mendasar dari data hasil survei dan juga riset di atas, penulis dapat menjawab pertanyaan yang telah disebutkan pada bagian sebelumnya. Media belum mampu secara optimal memberikan ruang publik yang digunakan untuk mendiskusikan isu isu terkait yang tengah berlangsung. Media sibuk dengan "agendanya sendiri" sehingga menurunkan kualitasnya sebagai media yang dapat menjadi partner masyarakat. Media hanya mementingkan kepentingannya sendiri untuk bisa mencapai tujuan yang telah direncanakan. Dengan kata lain bahwa media belum bisa mewujudkan ruang publik yang leluasa karena prosentase kepentingan pemilik media masih cenderung tinggi dibandingkan dengan warga. Kepentingan kepentingan pemilik tersebut tidak bisa ditunda dengan alasan biaya yang telah dikeluarkan tidaklah sedikit jumlahnya. Oleh karena itulah dalam memenuhi kepentingan tersebut, media mendesain sedemikian rupa sehingga kepentingan tersebut dapat "goals" dan bisnis yang dijalankan mendapatkan keuntungan yang besar.

Kedua, Mengapa media yang berfungsi sebagai pengawas pemerintah atau lembaga lembaga publik (watch-dog) masih cenderung rendah dan bahkan lebih mengedepankan kepentingan berbisnisnya?

Penelitian yang dilakukan oleh Yanuar Nugroho, dkk menghasilkan sebuah temuan bahwa pemilik media membuat media menjadi sebuah komoditas, dengan pemirsa diperlakukan hanya sebagai konsumen, bukan sebagai warga negara yang sah. Konsentrasi industri media yang terjadi melalui merger dan akuisisi antar perusahaan-perusahaan media telah mengancam semangat 'keragaman kepemilikan' dan 'keragaman informasi' di media. Beberapa merger dan akuisisi penting telah terjadi barubaru ini: Indosiar diakuisisi oleh Elang Mahkota Teknologi perusahaan holding dari SCTV; detik. com dibeli oleh CT Group, pemilik TransTV dan Trans7; sejumlah kanal televisi lokal juga diambil alih oleh perusahaan-perusahaan besar seperti Kelompok MNC dengan jaringan SindoTV dan Jawa Pos, yang memiliki jaringan televisinya sendiri. Undang-Undang dan 
regulasi sepertinya tidak mempunyai gigi dalam mengendalikan konsentrasi kepemilikan seperti ini. Lebih lanjut adanya pemusatan di industri media yang terjadi sebagai konsekuensi yang tak terhindarkan dari kepentingan modal yang mendorong perkembangan industri media di Indonesia. Oligopoli media yang terjadi saat ini membahayakan hak warga negara atas informasi karena industri media sudah berorientasi keuntungan dan perusahaan-perusahaan media telah mewakili gambaran bisnis yang menguntungkan yang dapat dibentuk oleh kepentingan pemilik dan dengan demikian, bisnis media menjadi sangat memberi manfaat bagi mereka yang mencari kekuasaan. Hal ini terutama menjadi kasus pada sejumlah pemilik media yang juga terafiliasi dengan dunia politik. Aburizal Bakrie, Ketua Umum Partai Golkar yang juga pemilik Viva Group dan Surya Paloh, pendiri partai politik NasDem yang juga pemilik Media Group, adalah dua contoh nyata atas tren ini. Ada persepsi umum yang semakin berkembang bahwa kepentingan pemilikpemilik media ini telah membahayakan hak warga negara terhadap media, karena mereka menggunakan media sebagai alat kampanye politik untuk mempengaruhi opini publik. Pendek kata, media telah menjadi sebuah mekanisme di mana para pebisnis dan politisi menyampaikan kepentingan mereka dan pada saat yang sama juga mengambil profit dari bisnisnya (Nugroho, Yanuar. et al, 2012).

Terkait dalam hal ini, Litbang Kompas turut menyatakan dari jajak pendapat tahun 2010 dan 2011, responden selalu berpandangan sama bahwa media tidak sepenuhnya berpihak pada kepentingan masyarakat. Pada jajak pendapat kali ini, lebih dari separuh bagian (53,6 persen) responden menyatakan media lebih condong membela kepentingan bisnisnya daripada kepentingan masyarakat (Sultani, Litbang Kompas 2012).

Dari beberapa hasil penelitian di atas secara jelas menjawab pertanyaan media yang sebagai pengawas pemerintah atau lembaga lembaga publik (watch-dog) masih cenderung rendah dan bahkan lebih mengedepankan kepentingan berbisnisnya. Media hanyadijadikan sebagai komoditas bisnis yang bisa meraup keuntungan dengan jumlah besar. Realitas inilah yang kemudian diperparah dengan berafiliasinya pemilik media dengan politik. Media sudah tidak lagi menjadi mitra masyarakat dalam mengontrol berbagai kebijakan pemerintah karena dalam hal ini pemilik media telah melunturkan sebagaimana fungsi aslinya. Pemilik yang telah tergabung dalam dunia politik hanya akan memikirkan politik praktis dengan menghiraukan keseimbangan informasi yang disajikan.

Ketiga, Mengapa media yang berfungsi sebagaiagen mobilisasidukungan warga terhadap suatu posisi politis tidak bisa menyeimbangkan konten dan cenderung hanya terfokus pada yang pemilik minta?

Konglomerasi media menjadi alasan utama mengapa media yang saat ini sajikan hanyalah berorientasi pada mobilisasi kepentingan praktis. Seluruh group yang tergabung dalam satu afiliasi konglomerasi akan secara masif memberitakan hal hal yang terkait dengan kepentingan pemilik. Di tengah praktik konglomerasi yang semakin pesat, ada agenda politik yang dijalankan dimana media mampu untuk mempengaruhi masyarakat dan juga membombardir dalam segala lapisan masyarakat. Melalui media massa, pemilik melakukan blow up sehingga permasalahan yang dapat diakomodir menjadi seperti isu berat yang tak berujung penyelesaiannya. Mobilisasi akan menyasar pada kumpulan kumpulan masyarakat seperti halnya Lembaga Swadaya Masyarakat (LSM), Organisasi Masyarakat, Komunitas Masyarakat, dan lain sebagainya. Hal ini dilakukan bahwa ada kecenderungan masyarakat apabila diberikan pendekatan oleh orang yang telah dikenalnya akan dengan sukarela dilakukan. Ironisnya hal yang demikian telah terjadi cukup lama semenjak bergulirnya reformasi. Media sudah tidak bisa memberikan edukasi kepada masyarakat terkait dengan partisipasi politik masyarakat. 
Contoh konkret yang pernah dialami Indonesia dalam hal demkorasi yaitu Pemilihan Gubernur DKI Jakarta pada 2017 silam yang didalamnya terpilih tiga pasangan kontestasi politik. Pasangan satu Agus Harimurti Yudhoyono-Sylviana Murni, pasangan dua Basuki Tjahaja Purnama-Djarot Saiful Hidayat, dan pasangan tiga Anies Baswedan-Sandiaga Uno, sedangkan yang lolos ke putaran kedua adalah pasangan Basuki Tjahaja PurnamaDjarot Saiful Hidayat, dan Anies BaswedanSandiaga Uno. Inilah yang menjadi awal mula pertikaian seluruh media bahkan seluruh lapisan masyarakat dalam memberikan dukungan politiknya. Isu agama menjadi tameng yang sangat ampuh ketika salah satu dari pasangan calon gubernur DKI beragama minoritas. Anies Baswedan-Sandiaga Uno yang didukung oleh partai Gerindra dan PKS terus melancarkan aksi blow up media yang menyudutkan salah satu pihak dari calon gubernur. Hingga pada puncaknya tercetuslah beberapa aksi aksi ormas yang ditunggangi kepentingan politik, seperti aksi 212 dan seterusnya. Media yang tergabung dalam dukungan terhadap pasangan Anies-Sandiaga terus melakukan mobilisasi politik kepada masyarakat untuk bisa memilih pemimpin yang "satu agama". Dengan dalih inilah masyarakat semakin geram karena diduga Basuki Tjahaja Purnama melakukan penghinaan terhadap agama Islam yang selanjutnya mengintervensi pemerintah untuk bertindak mengenakan sanksi pidana kepadanya. Hingga pada akhirnya kesemua hal ini hanya agenda politik pemilik media yang telah menjalin mitra untuk terus bisa menggiring opini masyarakat menjatuhkan salah satu pihak dengan memobilisir pesan pada pemberitaan. Efek yang ditimbulkan bukan hanya dipermalukan di mata dunia yang notabene negara demokrasi, akan tetapi "pelegalan isu" yang seperti inilah yang akan terus menjadi senjata utama bagi para pelaku politik untuk bisa meriah kekuasaannya di masa masa mendatang. Hal ini sebuah bukti nyata masyarakat sangatlah awam dalam memahami isi media dan sangat tidak relevan dengan nilai nilai Pancasila tentang beragama.

Pemaparan contoh di atas menghantarkan kita untuk bisa menelaah lebih luas kekebasan pers yang terbelenggu saat ini dan hingga terjadi perpecahan. Jawaban atas pertanyaan media sebagaiagen mobilisasi dukungan wargaterhadap suatu posisi politis tidak bisa menyeimbangkan konten dan cenderung hanya terfokus pada yang pemilik minta memang benar adanya. Karena dalam hal ini pemilik media yang juga sebagai konglomerat industri media telah mendapuk dirinya juga dalam dunia perpolitikan. Pemilik media hanya mengomando suara untuk disiarkan dan yang sesuai dengan kepentingannya. Segala bentuk konten yang ada diarahkan untuk bisa memobilisasi pendapat masyarakat untuk memiliki persepsi yang sama seperti kehendak pemilik media. Sehingga konten yang ada sangat tidak proporsional dalam menyajikan data, fakta yang sesungguhnya terjadi.

\section{Simpulan}

Di dalam era yang serba online seperti saat ini terjadi, konglomerasi media memang sangat berkaitan erat dengan konvergensi yang lebih mengedepankan aspek digitalisasi di dalam suatu konten. Hal ini tentu terjadi karena adanya kecanggihan teknologi yang efektif dan efisien dalam menunjang konvergensi. Media yang awalnya hanya bisa dinikmati melalui platform yang berbeda, kini hanya dengan satu platform bisa menikmati berbagai media seperti televisi, radio, media cetak online, dan lain sebagainya. Tentu hal tersebut merupakan suatu penemuan manusia yang sangat menghemat tenaga dan materi. Konten konten yang tersaji cenderung semakin baik dan lengkap karena berpadunya seluruh media.

Kecanggihan teknologi seperti yang saat ini tengah berlangsung tidak serta merta diikuti dengan kebebasan pers. Walaupun kebebasan pers telah di atur dalam Undang-Undang No.40 tahun 1999 tentang Pers akan tetapi pers yang ada seakan masih terbelenggu layaknya berada di era Orde Baru. Wartawan yang bekerja tidak lebih hanya sekedar "pekerja" yang dijadikan 
boneka oleh pemiliknya untuk senantiasa menuruti keinginan sang pemilik. Segala bentuk informasi baik dalam bentuk konten berita maupun hal hal lainnya diarahkan sesuai dengan kepentingannya. Hal tersebut tidak dibarengi juga dengan kesadaran masyarakat untuk berliterasi media. Akibatnya masyarakatlah yang menjadi korban korban media dalam terpaan konten konten yang tersaji.

Kesimpulan yang dapat ditarik berkaitan dengan konglomerasi media antara konvergensi media dan kebebasan berpendapat yaitu 1) Media belum bisa mewujudkan ruang publik yang leluasa karena prosentase kepentingan pemilik media masih cenderung tinggi dibandingkan dengan warga. Kepentingan kepentingan pemilik tersebut tidak bisa ditunda dengan alasan biaya yang telah dikeluarkan tidaklah sedikit jumlahnya. Oleh karena itulah dalam memenuhi kepentingan tersebut, media mendesain sedemikian rupa sehingga kepentingan tersebut dapat "goals" dan bisnis yang dijalankan mendapatkan keuntungan yang besar. 2) Media hanya dijadikan sebagai komoditas bisnis yang bisa meraup keuntungan dengan jumlah besar. Realitas inilah yang kemudian diperparah dengan berafiliasinya pemilik media dengan politik. Media sudah tidak lagi menjadi mitra masyarakat dalammengontrol berbagai kebijakan pemerintah karena dalam hal ini pemilik media telah melunturkan sebagaimana fungsi aslinya. Pemilik yang telah tergabung dalam dunia politik hanya akan memikirkan politik praktis dengan menghiraukan keseimbangan informasi yang disajikan. 3) Pemilik media yang juga sebagai konglomerat industri media telah mendapuk dirinya juga dalam dunia perpolitikan. Pemilik media hanya mengomando suara untuk disiarkan dan yang sesuai dengan kepentingannya. Segala bentuk konten yang ada diarahkan untuk bisa memobilisasi pendapat masyarakat untuk memiliki persepsi yang sama seperti kehendak pemilik media. Sehingga konten yang ada sangat tidak proporsional dalam menyajikan data, fakta yang sesungguhnya terjadi.

Melihat hasil kesimpulan di atas, terdapat beberapa hal yang dapat dilakukan saat ini dalam upaya penyelamatan kebebasan pers dan pendapat di tengah praktik konglomerasi media, antara lain:

1. Pemerintah selaku pemangku kebijakan harus mampu untuk mengatur secara ketat mengenai konten konten yang tersaji di dalam media massa. Bukan hanya konten yang berbau pornografi saja akan tetapi konten yang tidak proporsional yang lebih cenderung mengacu pada kepentingan pemilik, seperti halnya kepentingan politik praktis.

2. Terus menerus merevisi payung hukum yang dijadikan dasar hukum untuk mengatur segala bentuk konten yang terkait dengan konglomerasi media.

3. Sosialisasi pemerintah kepada masyarakat tentang pentingnya berliterasi media agar masyarakat mampu memfilter segala bentuk informasi dari media massa dan mengubah cara pandang masyarakat terhadap media bahwa media secara intrinsik menyelipkan kepentingan kepentingan pribadinya. Selain itu juga memberikan wawasan kepada masyarakat untuk tidak sepenuhnya mempercayai segala macam informasi yang berasal dari media massa sebelum dilakukannya pencarian kejelasan lebih lanjut.

\section{Daftar Pustaka}

Bartsch, Gerhard. (2008). Newspapers Must Diversify, Converge and Integrate. NEWSPAPER MAGAZINES, 1-2008. (http://www.quad techworld.com/ downloads/thinktank/nm1_2008.pdf)

Cottam, Martha. et al. (2004). Introduction to Political Psychology, Chapter 6. New Jersey: Lawrence Erlbaum Association, Inc., Publishers.

David, F.R. (2004). Manajemen Strategis: Konsep. Edisi ketujuh. Jakarta: PT. Prenhallindo.

Epkamarsa, Hutama. (2014). Perkembangan Konvergensi Media di Indonesia. Naskah 
Ringkas Makalah Non-Seminar. Depok, Departemen Komunikasi, Fakultas Ilmu Sosial dan Ilmu Politik, Universitas Indonesia.

Erianto, Dwi. (2016). Survei Litbang Kompas: Televisi, Dua Sisi Mata Uang. Kompas. com, 30 Maret. (http://nasional.kompas. com/read/2016/03/30/05374961/Survei. Litbang.Kompas.Televisi.Dua.Sisi.Mata. Uang akses 16/02/18 - 21.20 WIB)

Fahrudin, Dedi. (2013). Konglomerasi Media: Studi Ekonomi Politik Terhadap Media Group. Jurusan Komunikasi Penyiaran Islam, Fakultas Dakwah dan Ilmu Komunikasi, UIN Syarif Hidayatullah Jakarta. Jurnal Visi Komunikasi, Volume 12 No. 1, Mei.

Francis C., Baldesari (2006). Systematic Reviews of Qualitative Literature. Oxford: UK Cochrane Centre.

Hanifan, Aqwam Fiazmi. (2016). Menancapkan Mars Perindo lewat Stasiun TV milik Pribadi. Tirto.id, 15 Februari. (https:// tirto.id/menancapkan-mars-perindolewat-stasiun-tv-milik-pribadi-nn akses 16/02/2018 - 20.29 WIB)

Haritajaya, Olyvie Bintang. (2017). Skripsi: Pembredelan Pers di Masa Orde Baru (1966-1998). Yogyakarta: Program Studi Pendidikan Sejarah, Fakultas Keguruan dan Ilmu Pendidikan, Universitas Sanata Dharma.

Iklan Partai PERINDO (http://www.adstensity. com/service/compare - akses 16/02/18 $21.23 \mathrm{WIB})$.

Karman,. (2013). Media dan Kepentingan Publik: Praktik Media Massa Menurut Teori Normatif. Peneliti Bidang Komunikasi \& Media Balai Pengkajian dan Pengembangan Komunikasi dan Informatika (BPPKI) Jakarta, Badan Litbang SDM Kemenkominfo. INSANI, Vol. 2, No. 15 Desember.

Lewin, S. (2008). Methods to Synthesise Qualitative Evidence Alongside a Cochrane Intervention Review. London:
London School of Hygiene and Tropical Medicine.

Lim, Merlyna. (2011). @crossroads: Democratization \& Corporatization of Media in Indonesia, Participatory Media Lab University of Arizona \& Ford Foundation.

Malvi, Alvina. (2014). Skripsi: Representasi Citra Politik Iklan Hanura WIN-HT Bersih Peduli Tegas di RCTI. Jakarta: Jurusan Komunikasi dan Penyiaran Islam, Fakultas Dakwah dan Ilmu Komunikasi, Universitas Islam Negeri Syarif Hidayatullah.

Martono, Joko. (2014). Kebebasan Pers di Indonesia pada Era Reformasi dan Ekonomi Politik Media. Peneliti komunikasi dan media di BPPKI Yogyakarta, Kementerian Komunikasi dan Informatika RI. INSANI, Vol. 1, No. 1, Desember.

Norris, Pippa,(2000). A Virtuous Circle: Political Communications In PostIndustrial Societies. New York: Cambridge University Press.

Nugroho, Y., Putri, DA., Laksmi, S. (2012). Memetakan Lanskap Industri Media Kontemporer di Indonesia (Edisi Bahasa Indonesia). Laporan. Bermedia, MemberdayakanMasyarakat:Memahami kebijakan dan tata kelola media di Indonesia melalui kacamata hak warga negara. Riset kerjasama antara Centre for Innovation Policy and Governance dan HIVOS Kantor Regional Asia Tenggara, didanai oleh Ford Foundation. Jakarta: CIPG dan HIVOS.

Putra, I Gusti Ngurah. (2004). Demokrasi dan Kinerja Pers Indonesia. Jurnal Ilmu Komunikasi Universitas Gajah Mada, Vol. 3, No. 2, Juni.

Sanusi, Hartinah., Hamzah, Djabir., Unde, Andi Alimuddin. Manajemen Media Televisi Fajar TV: Antara Bisnis dan Idealisme (Broadcasting Media Management of FAJAR TV: Both Idealism and Business). 
(http://pasca.unhas.ac.id/jurnal/files/761 a5107f7981abffa899b367302a8b1.pdf)

Scheufele, D. A. (1999). Framing as a theory of media effects. Journal of Communication, 49(1), 103-122.

Setiawan, Aria Aditya. (2013). Peran Media Massa dalam Meningkatkan Kualitas Kepemerintahan Lokal Berbasis Human Security di Kota Jayapura. Politika: Jurnal Ilmu Politik, Vol. 2, No. 2, p. 3948, Juni.

Sultani,. (2012). Pers Belum Bisa Memberikan Solusi. Kompas.com, 03 Februari. (http://internasional.kompas.com/ read/2012/02/13/01565786/pers. belum.bisa.memberikan.solusi akses 16/02/2018 - 17.38 WIB)

Surjomiharjo, Abdurrchman. (2002). Beberapa Segi Perkembangan Sejarah Pers Di Indonesia. Jakarta: PT Kompas Media Nusantara.
Valerisha,Anggia.DampakPraktikKonglomerasi Media Terhadap Pencapaian Konsolidasi Demokrasi di Indonesia. Jurusan Hubungan Internasional, Universitas Katolik Parahyangan, Bandung.

Waluyo, Djoko. (2014). Kebebasan Pers dari Pandangan Wartawan (PWI dan AJI). Yogyakarta: Penerbit Tiara Wacana Lokus.

Peraturan Perundang-Undangan

Undang-Undang Dasar Republik Indonesia 1945 amandemen.

Piagam Hak Asasi Manusia Indonesia dalam Tap. MPR No. 18 Tahun 1998.

Undang-Undang No. 9 Tahun 1998 tentang Kemerdekaan Menyampaikan Pendapat di Muka Umum.

Undang-Undang No.40 tahun 1999 tentang Pers. 